\title{
KONTRIBUSI SARANA PENDIDIKAN TERHADAP KUALITAS PENDIDIKAN DI SEKOLAH
}

\author{
Oleh \\ I Made Ariasa Giri \\ Dosen pada Fakultas Dharma Acarya IHDN Denpasar
}

\begin{abstract}
Facilities in education are not merely those that are used in the classrooms, such as the classbooks, boards, rulers, and other learning aids, but also the ones that indirectly support the education manajemen, such as the land and building. At least such facilities should be provided in accordance with the need and function of the school (Depdiknas, 2003). Fullfilment of the need for such supporting facilities will contribute to the quality of the educational service.

There are three things that presumably can support directly the learning and achievement of the students, namely the availability of enough resources, educational aids, such as lab and workshop, and teaching medium. The absence of them will result in mere verbal teaching that cause the learning process to be less powerful. Students will only lean on the memoy for only learn to memorize things. It produces unauthentic learning pocess and situation and develop less learning experience. As the result the students acievement is low in all of its aspects, including the cognitive, attitude, skill, self-confidence, commitment, and competence.
\end{abstract}

\section{Key Words: Education facilities, quality}

\section{I.PENDAHULUAN}

Upaya meningkatkan mutu pendidikan di Indonesia bukanlah usaha yang mudah. Hal ini mengingat kesenjangan atau disparitas mutu pendidikan antar lembaga pendidikan di Indonesia, antara sekolah di desa dan di kota, misalnya, sangatlah senjang. Hal ini dapat diketahui, saat ini ada sekolah bahkan yang telah mampu berkembang menjadi lembaga pendidikan berstandar internasional dengan menjadi sekolah nasional berstandar internasional, ada sekolah yang berstandar nasional, tetapi ada juga sekolah yang bahkan belum memenuhi standar lokal..

Dengan begitu, sejalan dengan upaya peningkatan mutu pendidikan tersebut, dengan mempertimbangkan disparitas kondisi antar sekolah atau lembaga-lembaga pendidikan yang ada, baik pengambil kebijakan maupun pelaksana atau praktisi pendidikan di lapangan, dari pusat sampai ke daerahdaerah, tentu membutuhkan acuan bagi upaya pengembangan standar pendidikan yang dapat dijadikan pegangan oleh semua pihak dalam pelaksanaan program-program pendidikan nantinya maupun dalam mengevaluasi atau mengukur keberhasilan program pendidikan dalam peningkatan mutu kinerjanya. Dengan dasar pemikiran tersebutlah Undang-undang No. 20 Tahun 2003 tentang Sistem Pendidikan Nasional antara lain menegaskan perlunya pengembangan standar nasional pendidikan, yang antara lain mencakup: standar isi, standar proses, standar kompetensi lulusan, standar pendidik dan tenaga kependidikan, standar sarana dan prasarana, standar pengelolaan, standar pembiayaan, dan standar penilaian.

Sarana dan prasarana pendidikan merupakan salah satu unsur masukan pendidikan yang penting dan merupakan kebutuhan vital bagi terselenggaranya proses pendidikan yang berkualitas. Tanpa ditunjang oleh sarana dan prasarana yang memadai sulit diharapkan proses dan hasil pendidikan yang bermutu tinggi. Rendahnya kualitas proses dan hasil pendidikan di Indonesia saat ini, sebagian diduga disebabkan oleh minimnya sarana pendidikan yang disediakan oleh pemerintah maupun yang mampu disediakan oleh masyarakat. Sementara itu, minimnya ketersediaan sarana prasarana pendidikan tidak saja disebabkan oleh ketidakmampuan masyarakat atau pemerintah, tetapi juga tidak teridentifikasinya jenis sarana pendidikan yang paling esensial dibutuhkan agar suatu proses pendidikan berlangsung secara optimal. Dengan kata lain, pemerintah belum memiliki standar yang jelas tentang sarana pendidikan yang diperlukan untuk terwujudnya proses dan hasil pendidikan bermutu dan memiliki daya saing tinggi.

Ketiadaan sarana pendidikan dalam belajar cenderung akan membuat peserta didik akan belajar secara verbalisme belaka dan ini adalah salah satu 
bentuk penindasan intelek. Dalam hal penguasaan dan pengembangan teknologi, penggunaan sarana pendidikan yang dapat dikatakan sebagai teknologi pendidikan dalam proses belajar teknologi dapat memfasilitasi pebelajar untuk berinteraksi langsung dengan dunia teknologi yang memudahkan pemahaman mereka dan menghindari verbalisme.

Kebutuhan sarana pendidikan tidaklah cukup hanya yang berkaitan langsung dengan kegiatan belajar dan pembelajaran di kelas saja seperti buku sumber, peralatan, perabot, dan media pendidikan saja. Pendidikan di sekolah juga membutuhkan sarana pendidikan yang secara tidak langsung mendukung terlaksananya kegiatan belajar dan pembelajaran di kelas seperti kebutuhan lahan, bangunan atau ruang, serta peralatan dan perabot untuk terselenggaranya manajemen sekolah secara bermutu. Kebutuhan sarana pendidikan seperti ini secara minimal tentu disesuaikan dengan tingkat kebutuhan, jenis, dan fungsinya (Depdiknas, 2003). Kebutuhan sarana pendukung ini diperlukan untuk memberikan pelayanan yang optimal bagi berlangsungnya proses pendidikan yang bermutu.

Standar Nasional Pendidikan merupakan kriteria minimal tentang sistem pendidikan di seluruh wilayah hukum Negara Kesatuan Republik Indonesia. Lingkup Standar Nasional Pendidikan ini meliputi: standar isi, standar proses, standar kompetensi lulusan, standar pendidik dan tenaga kependidikan, standar sarana dan prasarana, standar pengelolaan, standar pembiayaan, dan standar penilaian seperti yang telah disebutkan di atas.

Berkaitan dengan standar sarana pendidikan dinyatakan bahwa setiap satuan pendidikan wajib memiliki sarana yang meliputi perabot, peralatan pendidikan, media pendidikan, buku dan sumber belajar lainnya, bahan habis pakai, serta perlengkapan lain yang diperlukan untuk menunjang proses pembelajaran yang teratur dan berkelanjutan, seperti keperluan gedung dan lahan (Depdiknas, 2003). Peraturan pemeritah ini belum menjabarkan lebih jauh apa jenis dan spesifikasi sarana pendidikan yang esensial dan seberapa besar kebutuhan minimal oleh masing-masing sekolah pada setiap jenjang dan jenis program pendidikan. Demikian pula rincian mengenai kebutuhan sarana esensial dan minimal untuk setiap jenis kegiatan manajemen pendidikan, proses belajar mengajar, dan proses evaluasi program.

Keterbatasan anggaran yang dimiliki pemerintah pusat maupun daerah mengisyaratkan pemerintah daerah agar memiliki data base yang jelas tentang jenis dan tingkat kebutuhan minimal sarana pendidikan pada setiap jenjang pendidikan, bahkan untuk setiap jenis kegiatan penyelenggaraan pendidikan. Kemampuan masyarakat dalam menyediakan sarana pendidikan di daerahnya sesuai dengan kondisi sosial ekonominya juga perlu diidentifikasi.. Selanjutnya perlu dikaji secara ilmiah pengembangan sarana pendidikan bagi sekolahsekolah di setiap jenjang untuk meningkatkan daya saing pendidikan di tingkat lokal, nasional, dan international. Tersediannya sarana pendidikan sekolah yang memadai juga diduga memiliki korelasi yang kuat dengan peningkatan kualitas proses dan hasil belajar program pendidikan di sekolah (Depdiknas, 2005a, 2005b). Dalam hal ini, sarana pendidikan, terutama yang menyangkut fasilitas pembelajaran, sumber belajar, dan media pembelajaran (Depdiknas, 2005b) diduga mempunyai pengaruh yang kuat terhadap peningkatan hasil belajar yang diharapkan. Sarana pembelajaran yang tepat di samping dapat menjadi media pendidikan (belajar) yang akan membantu mempermudah proses berpikir anak melalui konkritisasi objek-objek abstrak, juga dapat menjadi objek belajar itu sendiri yang akan membantu peserta didik memahami fenomenafenomena alam, sosial, budaya, dan teknologi secara langsung. Dengan kata lain, memanfaatkan sarana belajar dan pembelajaran yang memadai memungkinkan peserta didik tidak saja akan belajar how to know tetapi juga belajar how to do, how to be, dan how to live together. Pelibatan proses belajar secara utuh, komprehensif, dan powerful seperti ini jelas membantu peserta didik mewujudkan potensi belajarnya secara optimal (Santiyasa, 1999; Sukadi, 2004; Wahab, 2002).

\section{II.PEMBAHASAN \\ 2.1 Penetapan Kebutuhan Esensial Sarana Pendidikan}

Pembangunan Nasional bidang pendidikan dilaksanakan berdasarkan Pancasila dan UndangUndang Dasar 1945. Tujuannya adalah berkembangnya potensi peserta didik agar menjadi manusia yang beriman dan betakwa kepada Tuhan Yang Maha Esa, berakhlak mulia, sehat, cakap, kreatif, dan bertanggung jawab (UU RI No.20 Tahun 2003). Dalam konteks ini pemerintah, telah membangun dan mengembangkan satu sistem pendidikan nasional yang di dalammnya termasuk subsistem pendidikan dasar dan menengah. Pendidikan dasar dan menengah diarahkan untuk meletakkan dasar-dasar, nilai-nilai pengetahuan, keterampilan, dan sikap yang bermanfaat untuk menghadapi hidup pada masa mendatang (Propenas 2000-2004).

Telah disadari bahwa tingkat keberhasilan berbagai jenis dan jenjang pendidikan dipengaruhi oleh banyak komponen, di antaranya dipengaruhi 
oleh kualitas dan kuantitas komponen: 1) program pendidikan (termasuk di dalamnya kurikulum, silabus, bahan ajar, metode/media, alat peraga, dan alokasi waktu), 2) sarana dan prasarana (gedung, alat, perabot, bahan, buku, dll), 3) pendidik (guru, instruktur, pamong belajar, fasilitator, konselor, tutor, dan sebutan lain yang sesuai dengan kekhususannya) dan tenaga kependidikan yang mendukungnya, 4) partisipasi masyarakat/ stakeholders, dan 5) daya dukung lingkungan internal dan eksternal (Dirjen Dikdasmen, 2003).

Sarana pendidikan merupakan komponen integral dari penyelenggaraan pendidikan pada semua jenis dan jenjang pendidikan. Tanpa ditunjang oleh sarana yang memadai sulit diharapkan penyelenggaraan pendidikan yang menghasilkan sumber daya manusia yang berkualitas dan berdaya saing tinggi. Sumber daya manusia yang berkualitas itu, antara lain dicirikan oleh penguasaan iptek yang tinggi, penguasaan keterampilan di bidangnya, memiliki komitmen, nilai-nilai dan sikap yang positif terhadap kemajuan, bertanggung jawab atas seluruh bidang kerja yang digelutinya, mempunyai kecakapan sosial yang memadai, dan memiliki kepribadian serta keimanan yang mantap (Sukadi, 2005).

Salah satu faktor yang ditengarai sebagai penyebab rendahnya mutu penyelenggaraan pendidikan di Indonesia selama ini adalah kurangnya sarana prasarana pendidikan yang dapat disediakan oleh pemerintah, pemerintah daerah, dan masyarakat. Menyadari hal ini, Depatemen Pendidikan Nasional dalam Rencana Strategis tahun 2005-2009 telah mencanangkan program penyediaan sarana pendidikan yakni sarana belajar untuk meningkatkan mutu dan relevansi pendidikan mulai dari pendidikan dasar sampai pendidikan tinggi.

Sarana pendidikan menurut PP No.19 Tahun 2003 meliputi perabot, peralatan pendidikan, media pendidikan, buku dan sumber belajar lainnya, bahan habis pakai, serta perlengkapan lain yang diperlukan untuk menunjang proses pembelajaran yang teratur dan berkelanjutan. Sarana pendidikan menurut pengertian ini tidak secara tegas dan jelas memasukkan unsur kebutuhan lahan dan ruang bangunan menjadi bagian dari sarana pendidikan. Depdiknas (2003), selanjutnya, dalam Pedoman Analisis Kebutuhan Sarana Pendidikan Sekolah Menengah Kejuruan telah menetapkan bagian dari kebutuhan sarana pendidikan itu meliputi kebutuhan ruang bangunan, peralatan, perabot, dan kebutuhan lahan.

Bertolak dari UU RI. No.20 Tahun 2003 ini, pemerintah daerah berkewajiban untuk memenuhi sarana pendidikan untuk semua satuan dan jenjang pendidikan di wilayahnya yang menjadi tanggung jawab daerah. Pemerintah perlu mengidentifikasi bagaimana kualitas dan kuantitas sarana prasarana pendidikan yang ada saat ini di setiap jenjang pendidikan? Apakah keberadaan sarana dan prasarana ini telah memenuhi standar yang dipersyaratkan? Sejauh mana pemanfaatan saranaprasarana yang sudah ada dan kontribusinya terhadap peningkatan mutu dan relevansi pendidikan.

\subsection{Standar Minimal Sarana Pendidikan}

Dalam PP No.19 Tahun 2005 dijelaskan bahwa Standar Nasional Pendidikan meliputi: (1) Standar isi, (2) standar proses, (3) standar kompetensi lulusan, (4) standar pendidik dan tenaga kependidikan, (5) standar sarana dan prasarana, (6) standar pengelolaan, (7) standar pembiayaan, (8) standar penilaian pendidikan. Standar nasional pendidikan ini berfungsi sebagai dasar dalam perencanaan, pelaksanaan, dan pengawasan pendidikan dalam rangka mewujudkan pendidik nasional yang bermutu. Tujuan dari standar nasional pendidikan ini adalah mencerdaskan kehidupan bangsa dan membentuk watak serta peradaban bangsa yang bermartabat.

Dalam bab VII, PP No.19 Tahun 2003, secara khusus ditegaskan mengenai standar sarana dan prasarana. Dalam pasal 12 bab ini dinyatakan bahwa setiap satuan pendidikan wajib memiliki sarana yang meliputi perabot, peralatan pendidikan, media pendidikan, buku dan sumber belajar lainnya, bahan habis pakai, serta perlengkapan lain yang diperlukan untuk menunjang proses pembelajaran yang teratur dan berkelanjutan.

Selanjutnya pada pasl 43 diatur sebagai berikut: Standar keragaman jenis peralatan laboratorium ilmu pengetahuan alam (IPA), laboratorium bahasa, laboratorium komputer, dan peralatan pembelajaran lain pada satuan pendidikan dinyatakan dalam daftar yang berisi jenis minimal peralatan yang harus tersedia (ayat 1). Standar jumlah peralatan dinyatakan dalam rasio minimal jumlah peralatan per peserta didik (ayat 2). Standar buku dinyatakan dalam jumlah judul dan jenis buku di perpustakaan satuan pendidikan (ayat 3). Standar jumlah buku teks pelajaran di perpustakaan dinyatakan dalam rasio minimal jumlah buku teks pelajaran untuk masing-masing mata pelajaran di perpustakaan satuan pendidikan untuk setiap peserta didik (ayat 4). Standar sumber belajar lainnya untuk setiap satuan pendidikan dinyatakan dalam ratio jumlah sumber belajar terhadap peserta didik sesuai dengan jenis sumber belajar terhadap peserta didik sesuai dengan jenis sumber belajar dan 
karakteristik satuan pendidikan (ayat 6). Setiap satuan pendidikan, pemerintah daerah, maupun masyarakat dalam menyediakan sarana pendidikan harus mengacu pada ketentuan yang diatur dalam PPini.

Sesuai dengan pedoman ini, aktivitas pembelajaran sebagai aktivitas pokok pendidikan yang bertujuan memberdayakan dan mengembangkan kompetensi peserta didik haruslah menjadi dasar utama dalam penentuan kebutuhan sarana pendidikan di sekolah. Aktivitas pembelajaran ini secara empiris memiliki implikasi utama dalam menentukan kebutuhan sarana pendidikan baik secara langsung maupun tidak lansung agar pembelajaran itu sendiri berlangsung secara memadai, efektif, dan efisien dalam menghasilkan lulusan yang sesuai dengan tuntutan kebutuhan masyarakat, tuntutan perkembangan ilmu pengetahuan dan teknologi, serta tuntutan dunia kerja. Dengan begitu aktivitas pembelajaran dapat dianalisis implikasinya terhadap kebutuhan ruang dan dengan begitu memerlukan jumlah lahan tertentu untuk ruang bangunan, terhadap kebutuhan peralatan, perabot, sumber belajar, media pendidikan/ pembelajaran, alat tulis kantor dan bahan habis, serta sarana pendukung lainnya. Dari analisis implikasi seperti itu akan dihasilkan kebutuhan sarana pendidikan dalam jenis dan jumlahnya sesuai dengan tuntutan pengembangan kompetensi serta sesuai pula dengan fungsi atau kegunaan masing-masing jenis sarana dalam menunjang keberhasilan aktivitas pembelajaran berbasis kompetensi (Depdiknas, 2003).

\section{1) Kebutuhan Ruang/Bangunan}

Pada dasarnya penetapan kebutuhan ruang untuk program pendidikan pada tiap jenjang pendidikan dilakukan dengan pendekatan empirik dan studi referensi berdasarkan pengalaman masa lalu untuk melihat kebutuhan masa ini dan masa depan bagi peserta didik (Depdiknas, 2003). Karena itu perencanaan kebutuhan ruang disusun berdasarkan fungsi dan kegunaan ruang itu dalam proses pendidikan dan pembelajaran. Fungsi dan kegunaan ruang umumnya berkaitan dengan pihak-pihak yang menggunakan dan jenis kegiatan dari pihak-pihak pemakai. Dalam hal ini fungsi ruang umumnya diklasifikasi menjadi tiga bagian, yaitu: kelompok ruang pembelajaran, perkantoran, dan ruang penunjang pembelajaran. Dari segi pemakainya, kebutuhan ruang/bangunan dapat difungsikan untuk ruang kepala sekolah, ruang guru, ruang pegawai tata usaha, ruang aktivitas pembelajaran siswa, ruang tamu dan pihak luar (termasuk komite sekolah

\section{2) Kebutuhan Lahan}

Kebutuhan lahan untuk tiap-tiap jenjang dan jenis sekolah umumnya ditentukan atas kebutuhan minimal luas bangunan sesuai dengan fungsi dan kegunaanya ditambah dengan keperluan infrastruktur penunjang yang pokok diperlukan yang menurut pedoman standar minimal dari Depdiknas (2003) minimal mencapai 20\% dari luas lahan untuk keperluan bangunan. Karena itu perlu diidentifikasi jenis-jenis dan luas bangunan yang esensial dan minimal yang diperlukan untuk tiap-tiap sekolah dan selanjutnya dapat ditambahkan minimal $20 \%$

\section{3) Kebutuhan Peralatan Pendidikan}

Kebutuhan peralatan pendidikan disesuaikan dengan kebutuhan empiris di sekolah yang disesuaikan dengan tuntutan aktivitas utama pembelajaran berdasarkan kurikulum yang berlaku serta kebutuhan peralatan penunjang lainnya dalam keseluruhan aktivitas pendidikan di sekolah. Berdasarkan kebutuhan seperti itu maka kebutuhan jenis peralatan pendidikan yang diperlukan di sekolah dapat dikelompokkan, antara lain: peralatan /media pembelajaran, peralatan praktik laboratorium, peralatan administrasi perkantoran, dan peralatan penunjang terutama yang terkait dengan peralatan pemeliharaan dan perawatan (Depdiknas, 2003).

\section{4) Kebutuhan Perabot Pendidikan}

Perabot, oleh Depdiknas (2003) disamakan dengan mebeler yang terdiri dari mebeler yang dapat dipindahkan/disusun sesuai kebutuhan suatu waktu, seperti meja dan kursi tamu; dan mebeler yang tetap/ tidak dipindahkan dalam jangka waktu yang lama, seperti lemari besi tempat penyimpanan uang. Kebutuhan perabot di sekolah ditentukan oleh jenis kegiatan yang dilakukan di sekolah, kelompok pemakai, ruang penempatan perabot, serta jumlah pemakainya. Karena itu, komponen-komponen ini perlu dianalisis terlebih dahulu sebelum menentukan jenis dan jumlah perabot yang dibutuhkan di sekolah.

\section{5) Kebutuhan Sumber Belajar}

Sarana sumber belajar di sekolah adalah segala sesuatu yang dapat digunakan sebagai sarana untuk memperoleh informasi belajar, antara lain berupa buku paket, buku penunjang, LKS, jurnal atau majalah, majalah mingguan, surat kabar harian, komputer dengan media internet, televisi pendidikan, radio, laporan penelitian, dan sejenisnya.

Kebutuhan masing-masing jenis sumber belajar tersebut akan sangat tergantung pada tingkat urgensi sumber belajar tersebut, fungsi dan kegunaan sumber 
belajar tersebut dalam menunjang pencapaian tujuan pengembangan kompetensi sesuai dengan tuntutan standar kurikulum, pemakainya, dan jumlah pemakai. Untuk buku paket/ajar pegangan guru dan siswa, LKS, dan buku-buku penunjang utama umumnya adalah sumber belajar yang paling vital dibutuhkan baik oleh guru maupun siswa. Karena itu, kebutuhannya haruslah dipenuhi secara individual dan akan sangat tergantung pada jumlah guru dan siswa.

Untuk kebutuhan buku-buku pendukung baik yang bersifat ilmiah, populer, maupun buku fiksi serta jurnal urgensinya jelas tidak seutama buku-buku ajar, LKS, dan buku-buku penunjang buku ajar utama. Karena itu, kebutuhannya tentu akan sangat tergantung pada urgensi sumber-sumber tersebut baik bagi guru maupun siswa serta berdasarkan data penggunaan sebelumnya. Buku-buku pendukung yang keberadaannya sangat dibutuhkan dan sering digunakan kebutuhannya tentu lebih banyak dari pada buku-buku pendukung yang kurang kebutuhannya dan jarang digunakan sebelumnya. Begitu pula dengan sumber-sumber belajar yang berupa laporan penelitian.

\subsection{Peran Pemerintah Daerah dan Masyarakat dalam Penyelenggaraan Pendidikan}

Sejak diundangkannya UU No. 22 tahun 1999 tentang Pemerintahan Daerah, daerah diberi kewenangan untuk mengatur dan mengurus kepentingan masyarakat setempat menurut prakarsa sendiri berdasarkan aspirasi masyarakat sesuai dengan peraturan perundang-undangan. Kewenangan diberikan kepada daerah dalam wujud otonomi luas, nyata, dan bertanggung jawab.

Kewenangan daerah kabupaten dan kota, sebagaimana dirumuskan dalam pasal 11, mencakup semua bidang pemerintahan, yakni pekerjaan umum, kesehatan, pendidikan dan kebudayaan, pertanian, perhubungan, industri dan perdagangan, penanaman modal, lingkungan hidup, pertanahan, koperasi serta tenaga kerja. Jelaslah bahwa kebijakan pendidikan berada di bawah kewenangan daerah kabupaten dan kota. Konsekwensi dari keluarnya undang-undang pemerintahan daerah tersebut adalah terjadinya perubahan dalam berbagai bidang penyelenggaraan kehidupan pemerintahan, salah satunya adalah penyelenggaraan pendidikan. Jika sebelumnya manajemen pendidikan merupakan wewenang pusat, dengan berlakunya undang-undang tersebut manajemen pendidikan menjadi wewenang pemerintah kabupaten dan kota.

Selain dalam undang-undang pemerintah daerah, kewenangan dan tanggung jawab pemerintah daerah dalam penyelenggaraan dan pembiayaan pendidikan juga diatur dalam UU RI No.20 tahun 2003, tentang Sistem Pendidikan Nasional. Sesuai dengan UU RI No. 20 Tahun 2003 tanggung jawab pemerintah daerah dalam penyelenggaraan pendidikan di daerah bersangkutan sangat esensial. Sebagaimana ditegaskan dalam pasal 10 undangundang ini, bahwa pemerintah dan pemerintah daerah berhak mengarahkan, membimbing, membantu, dan mengawasi penyelenggaraan pendidikan sesuai dengan peraturan dan perundang-undangan yang berlaku. Pemerintah daerah bersama-sama pemerintah wajib memberikan layanan dan kemudahan, serta menjamin terselenggaranya pendidikan yang bermutu tinggi bagi setiap warga negara tanpa diskriminasi. Pemerintah daerah juga berkewajiban menyediakan dana guna terselenggaranya pendidikan bagi setiap warga negara yang berusia tujuh sampai lima belas tahun. Secara lebih tegas mengenai pembiayaan pendidikan dinyatakan bahwa pemerintah daerah harus mengalokasikan dana pendidikan sebesar $20 \%$ dari Aggaran Pendapatan dan Belanja Daerah (APBD).

\subsection{Kontribusi Sarana Pendidikan terhadap Kualitas Pendidikan}

Semangat otonomi daerah telah mengilhami munculnya pemikiran ke arah pengelolaan pendidikan yang memberi keleluasaan kepada sekolah untuk mengatur dan melaksanakan berbagai kebijakan secara luas. Pemikiran ini dalam perjalanannya disebut manajemen peningkatan mutu berbasis sekolah (MPMBS) (Mulyasa, 2002). Tujuan utama MPMBS adalah meningkatkan efisiensi, mutu, dam pemerataan pendidikan. Peningkatan efisiensi diperoleh melalui keleluasaan mengelola sumber daya yang ada, partipasi masyarakat, dan penyederhanaan birokrasi. Peningkatan mutu diperoleh melalui partisipasi orang tua, kelenturan pengelolaan sekolah, peningkatan profesionalisme guru, adanya hadiah dan hukuman sebagai kontrol, serta hal lain yang dapat menumbuhkembangkan suasana kondusif. Pemerataan pendidikan tampak dari tumbuhnya partisipasi masyarakat terutama yang mampu dan peduli, sementara yang kurang mampu akan menjadi tanggung jawab negara.

Secara umum mutu adalah gambaran dan karakteritik menyeluruh dari barang atau jasa yang menunjukkann kemampuannya dalam memuaskan pelanggan yang diharapkan atau tersirat. Dalam konteks pendidikan, pengertian mutu mencakup input, proses dan output pendidikan (Depdiknas, 2002:7). Input pendidikan adalah segala sesuatu yang harus tersedia unuk berlangsungnya proses 
pendidikan. Input pendidikan dapat berupa sumber daya dan perangkat lunak serta harapan-harapan sebagai pemandu berlangsungnya proses. Input sumber daya meliputi sumber daya manusia dan sumber daya selebihnya termasuk sarana prasarana pendidikan. Tinggi rendahnya mutu input dapat diukur dari tingkat kesiapan input.

Proses pendidikan merupakan berubahnya sesuatu menjadi sesuatu yang lain. Sesuatu yang berpengaruh terhadap berlangsungnya proses disebut input, sedangkan hasil dari proses pendidikan disebut output pendidikan. Dalam pendidikan berskala mikro (sekolah) yang dimaksud dengan proses adalah pengambilan keputusan, pengelolaan kelembagaan, pengelolaan program, proses belajar mengajar, dan proses monitoring dan evaluasi. Proses pendidikan bermutu tinggi apabila pengkoordinasian dan penyerasian serta pemanduan input sekolah dilakukan secara harmonis, mampu mendorong motivasi dan minat belajar, dan benarbenar mampu memberdayakan peserta didik.

Output pendidikan merupakan kinerja sekolah. Kinerja sekolah adalah prestasi sekolah yang dihasilkan dari proses/prilaku sekolah. Prilaku sekolah dapat dukur kualitasnya, efektifitasnya, produktivtasnya, efisiensi, inovasi, kualitas kehidupan kerjanya, dan moral kerjanya. Output sekolah dikatakan berkualitas tinggi apabila prestasi sekolah khususnya prestasi belajar siswa menunjukkan pencapaian yang tinggi. Prestasi belajar siswa dapat berupa prestasi akademik dan nonakademik. Prestasi akademik berupa nilai ulangan umum, ujian sekolah, ujian nasional, kualitas karya ilmiah, dan lomba-lomba akademik; sedangkan prestasi non-akademik berupa ketakwaan terhadap Tuhan Yang Maha Esa, kejujuran, kesopanan, kecakapan olah raga, kemampuan berkesenian, keterampilan dan kegiatan-kegiatan ekstrakurikuler lainnya.

Khusus dalam kaitannya dengan proses belajar mengajar, ketersediaan sarana pendidikan (khususnya material pembelajaran) yang memadai dan dengan jenis yang beragam serta dengan pengelolaan dan penggunaan yang tetapt akan meningkatkan kualitas pembelajaran, karena akan memberikan kesempatan pada pebelajar untuk belajar melalui pengalaman (first hand experiences) secara individu maupun kelompok (Trowbridge \& Bybee, 1990; Collette \& Ciappetta, 1994; Peter \& Gega, 2002). Dalam kaitan ini, Klausner (1996) menyatakan bahwa untuk dapat belajar sains melalui inkuiri, siswa harus disediakan sarana/fasilitas belajar selengkap mungkin, untuk memberikan kesempatan menggunakan sesering mungkin peralatan, buku sumber, dan sumber belajar lainnya untuk melakukan eksperimen dan pengamatan langsung terhadap penomena alam. Penganut paham konstruktivisme dengan pembelajaran kontekstualnya menyatakan bahwa pembelajaran kontekstual haruslah melibatkan aktivitas inkuiri dan penggunaan model dalam belajar. Aktivitas inkuiri dan pemodelan tentu tidak akan dapat dilakukan dengan baik tanpa adanya alat bantu dan media pembelajaran serta sumber-sumber belajar yang memadai. Itu artinya pembelajaran kontekstual yang akan memberikan pengalaman belajar yang lebih autentik dan powerful kepada siswa jika tidak disertai dukungan sarana belajar dan pembelajaran yang memadai tentu akan memberikan hasil yang kurang memadai pula (Sukadi, 2005).

Keterbatasan sarana pendidikan (peralatan laboratorium IPA, IPS, Bahasa; buku sumber; media pembelajaran, dll) yang tersedia selama ini cenderung mendorong proses pembelajaran tidak sesuai dengan hakikat subject matter dan kompetensi yang dituntut dalam kurikulm, sehingga pembelajaran menjadi kurang efektif dan membosankan serta bersifat verbalisme belaka. Pembelajaran yang mestinya dilakukan lewat pengalaman (learning by experience) dan belajar melalui partisipasi (learning by doing), terpaksa dilakukan dengan ceramah. Keadaan ini terjadi pada hampir semua disiplin ilmu (IPA dan IPS), dari tingkat sekolah dasar sampai perguruan tinggi. Jadi di samping komponen lainnya, sarana pendidikan juga memberikan kontribusi yang signifikan pada kualitas proses dan hasil pendidikan.

Ada tiga jenis sarana pendidikan yang diduga secara langsung akan mempengaruhi kualitas proses pembelajaran dan pada gilirannya akan mempengaruhi prestasi belajar siswa. Ketiga jenis sarana pendidikan itu adalah dukungan penggunaan sumber-sumber belajar yang memadai, dukungan peralatan pendidikan dan pembelajaran termasuk peralatan laboratorium dan bengkel kerja, serta dukungan penggunaan media pembelajaran. Ketiga jenis sarana pendidikan ini memang mempunyai hubungan langsung dengan kepentingan proses belajar siswa. Dapat diduga bahwa proses belajar dan pembelajaran yang kurang menggunakan dukungan ketiga jenis sarana ini akan mengakibatkan proses belajar siswa menjadi verbalisme belaka dan hasil belajarnya akan menjadi kurang bermakna dan powerful. Bersifat verbalisme karena pembelajaran hanya akan dilakukan melalui penguasaan bahasa verbal dan hanya melibatkan proses mengingat atau proses memori kerja belaka. Kurang bermakna, selanjutnya, karena belajar menjadi kurang autentik dan kurang berhubungan dengan pengembangan pengalaman belajar siswa yang nyata dan kurang 
berhubungan dengan lingkungan belajar yang lebih autentik. Belajar yang kurang bermakna dan kurang powerful akan bermuara pada prestasi belajar yang rendah baik dari domain kognisi, nilai-nilai dan sikap, keterampilan, penumbuhan rasa percaya diri (selfconfidence), pembinaan komitmen, maupun pengembangan kompetensinya (NCSS, 2000; Sukadi, 2005).

\section{III.PENUTUP}

Berdasarkan uraian tersebut di atas, maka dapatlah disimpulkan beberapa hal sebagai berikut.

1. Kebutuhan esensial sarana pendidikan bagi jenjang pendidikan dapat dikategorikan menjadi kebutuhan ruang/bangunan, kebutuhan perabot, kebutuhan peralatan/ media pendidikan, kebutuhan sumber belajar, dan kebutuhan lahan. Seluruh penentuan kebutuhan sarana pendidikan ini didasarkan pendekatan empiris dengan mempertimbangkan faktor utama jumlah siswa, sifat, fungsi, dan kegunaan sarana pendidikan, serta pemakai yang terlibat dalam proses pendidikan di sekolah.

2. Dengan asumsi-asumsi rasio jumlah siswa yang ditetapkan dengan pendekatan empiris dan studi perbandingan, pada jenjang pendidikan sekolah pemenuhan kebutuhan minimal sarana pendidikan ternyata masih relatif sangat rendah baik pada kebutuhan ruang/bangunan, perabot, peralatan / media pendidikan, sumber belajar, maupun kebutuhan lahan. Karena itu masih dirasakan banyak kekurangan untuk memenuhi standar minimal kebutuhan sarana pendidikan. Untuk kekurangan tersebut pihak sekolah terutama mengharapkan bantuan pihak pemerintah baik daerah kabupaten, propinsi, maupun pusat dalam alokasi APBD dan APBN terutama dalam memenuhi beberapa kekurangan sarana pendidikan yang menyangkut kebutuhan ruang bangunan, kebutuhan perabot utama, peraralatan dan media pendidikan, serta sumber-sumber belajar penunjang untuk pengayaan.

3. Berdasarkan hasil studi korelasi ditemukan bahwa seluruh faktor sarana pendidikan mempunyai kontribusi yang signifikan dalam menjelaskan variabilitas prestasi belajar siswa baik prestasi dalam ujian nasional maupun ujian sekolah. Secara sendiri-sendiri keberadaan faktor perabot, peralatan, dan sumber belajar ternyata merupakan faktor yang paling signifikan.

\section{DAFTAR PUSTAKA}

Bafadal, I. (2004). Manajemen Perlengkapan Sekolah, Teori dan Aplikasinya. Jakarta: Bumi Aksara.

Collette, A.T \& Chiappetta, E.L. 1994). Science Instruction in The Middle and Secondary School. Trhird Edition. Sydney: Maxwell Macillan.

Depdiknas. (2005a). Praktek Baik dalamPenjaminan Mutu Pendidikan Tinggi. Buku V: Prasarana dan Sarana. Jakarta: Depdiknas.

Depdiknas. (2005b). Draft 2 Rencana Strategis Departemen Pendidikan Nasional Tahun 2005-2009. Jakarta: Depdiknas.

Depdiknas. (2002). Manajemen Peningkatan Mutu Berbasis Sekolah. Buku 1. Konsep dasar. Jakarta: Depdiknas.

Depdiknas. (2003a). Kurikulum 2004. Standar Kompetensi Mata Pelajaran Sains. Sekolah menengah Pertama dan Madrasah Tsanawiyah. Jakarta: Depdiknas.

(2003b). Pedoman Analisis Kebutuhan Sarana Pendidikan Sekolah Menengah Kejuruan (SMK): Program Keahlian Teknik Elektronika Komunikasi. Jakarta: Depdiknas.

(2006). Petunjuk Pelaksanaan Program Subsidi Imbal Swadaya Pembangunan RKB, Perpustakaan dan Laboratorium IPA Sekolah Menengah Pertama dengan Mekanisme Partisipasi Masyarakat. Jakarta: Depdiknas.

Dirjen Dikdasmen. (2003). Kebijakan Pengembangan Kurikulum, Manaje-men Suplai dan Kebutuhan Guru Pendidikan Dasar dan Menengah Pada Era Otonomi dan Implemen-tasinya Untuk Pengembangan LPTK Masa Depan. Makalah. Disampaikan Dalam Rapat Kerja Pimpinan LPTK di Lingkungan Depdiknas. Di Jakarta Tanggal 10-12 Oktober 2003.

Kertiasa, Nyoman, dkk (1979) Petunjuk Pengelolaan Laboratorium IPA SMA 1. Jakarta: Departemen Pendidkan dan Kebudayaan.

Klausner, R (Chairman). (1996). National Science Education Standards. Washington DC: National Academy Press. 
Mulyasa, E. (2002). Manajemen Berbasis Sekolah. Konsep, Strategi dan Implementasi. Bandung: Remaja Rosdakarya

Peters, J.M \& Gega, Peter C. (2002). Science in Elementary Education. $9^{\text {th }}$ Edition. Ohio: Merril Prenice Hall.

Pusat Kurikulum, Balitbang Depdiknas. (2002). Kurikulum dan Hasil Belajar. Jakarta: Depdiknas.

Anonim, (2005). Peraturan Pemerintah Republik Indonesia No 19 Tahun 2005. Tentang Standar Nasional Pendidikan.

Santiyasa, I W. (1999). Pembelajaran Modul dengan Metode Demonstrasi dan Analogi sebagai Strategi Pengubah Konsepsi Mahasiswa Jurusan Pendidikan MIPA STKIP Singaraja. Laporan Penelitian. Singaraja: STKIP Singaraja.

Sevilla, C.G, dkk. (1983). Pengantar Metodologi Penelitian. Terjemahan. Jakarta: UI Press.

Sukadi. (2005). Penyusunan Standar Minimal Laboratorium Jurusan Pendidikan NonMIPA di Lingkungan IKIP Negeri Singaraja dalam Upaya Meningkatkan Standar Kompetensi Lulusan. Makalah. Disampiakan pada seminar P3AI menentukan standar minimal laboratorium, tgl 19 Nopember 2005.
Sukadi. (2004). Pembelajaran Mata Kuliah Belajar dan Pembelajaran Menggunakan Modeling Dosen Berbasis Konstruktivisme Pada Mahasiswa Semester III Jurusan PPKN IKIP Negeri Singaraja Tahun 2005/2006. Laporan Penelitian. Singaraja: IKIP Negeri Singaraja.

Tim Redaksi Fokusmedia. (2003). Himpunan Perundang-Undangan. Undang-Undang RI No.20 Tahun 2003 Tentang Sistem Pendidikan Nasional. Dilengkapi dengan Undang_undang No. 2 Tahun 1989 Tentang Sistem Pendidikan Nasional. Bandung: Fokusmedia.

Trowbridge, L.W. \& Bybee, R.W. (1990). Becoming A Secondary School Science Teacher. Fifth Edition. London. Merril Publishing Company.

Tim Redaksi Sinar Grafika. (1999). Undang-Undang Otonomi Daerah 1999. Jakarta: Sinar Grafika.

Wahab, A. A. (2002). Guru Profesional dan PIPS yang Kuat Prasyarat bagi Keberhasilan Implementasi Kurikulum Sekolah Berbasis Kompetensi. Makalah. Disampaikan pada Seminar Nasional Sehari IPS, FPIPS IKIP Negeri Singaraja, Tanggal 10 Agustus 2002. 